\title{
STRATEGI PENGEMBANGAN DESTINASI PARIWISATA KOTA BANDUNG DALAM MENINGKATKAN TINGKAT KUNJUNGAN WISATAWAN ASAL MALAYSIA
}

\author{
Khoirul Fajri ${ }^{1}$ \\ STIEPAR YAPARI, Bandung: khoirul.fajri@yahoo.com \\ Nova Riyanto E.S 2 \\ Mahasiswa STIEPAR YAPARI, Bandung. Prodi Usaha Perjalanan Wisata: \\ novarez10@gmail.com
}

\begin{abstract}
ABSTRAK
Seiring dengan perkembangan pariwisata di kota-kota lain di Indonesia selain Bandung, kondisi jumlah wisatawan baik domestik maupun mancanegara secara perlahan mulai menyebar ke beberapa kota. Jumlah wisatawan Malaysia ke Bandung pada bulan Januari hingga Maret dari tahun 2014 hingga 2016 sangat bervariasi. Dengan jumlah daya tarik wisata yang ada di Bandung saat ini jumlah wisatawan Malaysia tersebut akan dapat dipertahankan dan menjadi bertambah atau berkurang dikarenakan tingkat kejenuhan terhadap variasi paket wisata kota Bandung. Selain itu, faktor lain seperti pembukaan rute-rute penerbangan baru oleh Air Asia dari Malaysia ke beberapa kota di Indonesia.

Dari kondisi tersebut penulis melakukan penelitian menggunakan metode deskriptif pada bulan April hingga Juni 2016 dengan teknik pengumpulan data melalui studi literature atau dokumentasi, observasi, kuesioner dan interview, dapat disimpulkan bahwa kota Bandung sebagai destinasi pariwisata di Indonesia masih minim akan daya tarik wisata yang dapat ditawarkan kepada wisatawan asal Malaysia. Adapun responden terdiri dari beberapa asosiasi perusahaan pariwisata, maskapai penerbangan, instansi pemerintah dan wisatawan asal Malaysia itu sendiri yang diambil menjadi sampel sebagai responden sebanyak 100 wisatawan dengan perhitungan sampel menggunakan rumus slovink, dimana tingkat kesalahan sebesar $10 \%$ dari jumlah rata-rata wisatawan asal Malaysia dengan populasi sebanyak 19.235 orang setiap triwulan pertama per tahunnya.
\end{abstract}

Kata kunci: Bandung, Pariwisata, atraksi wisata, Wisatawan Malaysia.

\section{DEVELOPMENT STRATEGY OF TOURISM DESTINATIONS IN BANDUNG TO INCREASE THE LEVEL OF TOURIST VISIT FROM MALAYSIA}

\author{
ABSTRACT \\ Along with the development of tourism in other cities in Indonesia in \\ addition to Bandung, the condition of the number of tourists, both domestic and
}


foreign tourists are slowly beginning to spread to several cities. The numbers of tourists Malaysia to Bandung in January to March from 2014 to 2016 vary widely. With the number of tourist attraction in Bandung today the number of Malaysian tourists will be maintained and be increased or decreased due to the variation in the saturation level of the city of Bandung tour packages. In addition, other factors such as the opening of new flight routes by Air Asia from Malaysia to several cities in Indonesia.

This study used descriptive method by using two data collections, the primary data were observation, questionaire, and interview. Moreover, the secondary data is study literature. The respondents consisted of several associations of tourism companies, airlines, government agencies and tourists from Malaysia itself drawn into the sample as respondents as many as 100 travelers with sample calculations using formulas slovink in which an error rate of $10 \%$ of the total average rating from Malaysia with a population of 19235 people per year every first quarter. The result shows that the city of Bandung as a tourism destination in Indonesia is still low that can be offered to tourists from Malaysia.

Key word: Bandung, Tourism, Tourist attraction, Tourist from Malaysia.

\section{PENDAHULUAN}

Perkembangan pariwisata di Indonesia saat ini didorong untuk menjadi salah satu sektor yang memberikan andil besar dalam pengembangan perekonomian dan peningkatan kesejahteraan rakyat. Hal tersebut didorong oleh perkembangan dunia pariwisata Indonesia yang terus mengalami peningkatan dari waktu ke waktu, terlihat dari bertambahnya jumlah wisatawan yang berkunjung ke daerah tujuan wisata di Indonesia, yang terkenal dengan keindahan alam, keramahan penduduk, dan keanekaragaman budayanya. Pada tingkat daerah, sektor ini diperkirakan akan menjadi penunjang pendapatan daerah yang kontribusinya di masa mendatang memiliki prospek yang menguntungkan. Hal tersebut juga menjadi prioritas pemerintah kota Bandung dimana sektor pariwisata merupakan salah satu sektor yang diharapkan mampu mendukung pendapatan asli daerah.

Dalam usaha merealisasikan pembangunan dan pengembangan sektor pariwisata sebagai pendukung pendapatan asli daerah tersebut, pemerintah kota Bandung melakukan penetapan langkah-langkah sebagai penjabaran dari Visi dan Misinya dalam perda no. 13 tahun 2007 tentang tugas pokok dan fungsi dinas kebudayaan dan pariwisata kota Bandung yaitu ;

1. Terwujudnya pengembangan kepariwisataan dan kebudayaan;

2. Meningkatnya daya tarik wisata, jumlah kunjungan, dan lama tinggal wisata;

3. Terwujudnya sapta pesona;

4. Terwujudnya pelestarian dan pemuliaan kebudayaan daerah;

5. Meningkatnya konstribusi pariwisata terhadap perekonomian kota;

6. Berkembangnya kerjasama promosi, jumlah kunjungan dan pasar wisatawan; 
7. Meningkatnya kerjasama lintas sektor;

8. Meningkatnya kerjasama teknis dan litbang;

9. Berkembangnya kualitas aparatur dan pelaku pariwisata dan kebudayaan;

10. Berkembangnya kebudayaan daerah;

11. Bertumbuhnya usaha kepariwisataan;

12. Meningkatnya pemanfaatan LITBANG dan IPTEK dalam pengembangan kepariwisataan dan kebudayaan.

Dengan berhasilnya pemkot kota Bandung dalam mendapatkan ketetapan kota Bandung sebagai salah satu kota tujuan wisata dunia sebagaimana yang telah ditetapkan oleh UNESCO tanggal 25 september 2013 di Kota Beijing (http://www1.jabarprov.go.id/index.php/news/7445/2013/10/16, 2016), hal ini merupakan bukti kesungguhan pemerintah kota Bandung dalam melakukan pembangunan di bidang pariwisatanya. Selain itu terlihat juga dari perkembangan sarana transportasi penerbangan untuk rute-rute khususnya dari Bandung ke luar negeri atau sebaliknya, sebagai contoh sejak 1 Desember 2013, perusahaan penerbangan Air Asia Indonesia terus menambahkan frekwensi penerbangannya untuk rute dari Kualalumpur dan Johor Bahru ke Bandung atau sebaliknya, untuk rute Kualalumpur dari 3x per hari menjadi 4x per hari. (www.airasia.com ,2016), sehingga terlihat dengan jelas dalam tabel berikut peningkatan jumlah wisatawan asal Malaysia.

Tabel 1

Kunjungan Wisatawan Malaysia ke Kota Bandung

\begin{tabular}{|l|l|c|}
\hline Tahun & Bulan & Jumlah Wisatawan \\
\hline 2014 & Januari - Maret & $\mathbf{1 7 . 2 1 0}$ \\
\hline 2015 & Januari - Maret & $\mathbf{1 9 . 4 3 5}$ \\
\hline 2016 & Januari - Maret & $\mathbf{2 1 . 1 1 5}$ \\
\hline
\end{tabular}

Sumber : Dinas Kebudayaan dan Pariwisata Kota Bandung dan diolah kembali oleh penulis, 2016

Namun semua usaha yang telah dilakukan dan beberapa prestasi yang didapatkan hingga tahun 2014 oleh kota Bandung dalam hal kepariwisataan khususnya dalam rangka meningkatkan kunjungan wisatawan mancanegara asal Malaysia perlu terus dievaluasi dan ditingkatkan kembali karena tidak menutup kemungkinan jumlah wisatawan asal Malaysia tersebut tidak akan terus meningkat bahkan dapat berangsur-angsur turun. Untuk itu pemerintah kota Bandung tidak boleh terlena dengan kondisi jumlah kedatangan wisatawan asal Malaysia yang masih terus mengalami kenaikkan meskipun kenaikkannya belum dapat dikatakan sangat signifikan, akan tetapi guna menjaga stabilitas atau peningkatan jumlah kunjungan wisatawan asal Malaysia pemerintah kota Bandung harus melakukan terobosan-terobosan strategi dalam mengembangkan pariwisatanya, salah satu yang perlu menjadi pokok perhatian adalah pengembangan destinasi dan atraksi wisatanya.

Hal ini harus disadari oleh pemerintah kota Bandung, sesuai dengan data yang ada bahwa mayoritas wisatawan asal Malaysia tersebut masih terfokus untuk 
tujuan wisata belanja sehingga perlu dipikirkan dan direncanakan langkahlangkah pengembangan lebih lanjut dalam mempersiapkan tempat-tempat yang ada di area kota Bandung untuk menjadi beberapa destinasi wisata yang dapat ditawarkan kepada wisatawan disamping destinasi kawasan belanja. Sehingga penyebaran arus kunjungan wisatawan asal Malaysia yang datang berkunjung ke Bandung dapat dilakukan penyebarannya secara merata serta secara tidak langsung sekaligus melakukan kegiatan promosi bagi destinasi-destinasi wisata baru yang sudah mulai dikembangkan.

Dalam data tentang jumlah daya tarik wisata yang ada di Bandung hingga bulan Maret 2016 terlihat dalam tabel dibawah.

Tabel 2

Jumlah Daya Tarik Wisata di Kota Bandung

\begin{tabular}{|l|c|c|c|}
\hline \multicolumn{1}{|c|}{$\begin{array}{c}\text { Jenis Destinasi \& Sarana } \\
\text { Wisata }\end{array}$} & $\mathbf{2 0 1 3}$ & $\mathbf{2 0 1 4}$ & $\mathbf{2 0 1 5}$ \\
\hline Museum & 5 & 5 & 5 \\
\hline Pusat Pertunjukan seni & 3 & 2 & 2 \\
\hline Kawasan Belanja \& Kuliner & 76 & 83 & 95 \\
\hline Bioskop & 15 & 13 & 12 \\
\hline Billiard dan Pub/Diskotek & 60 & 77 & 82 \\
\hline Karaoke dan Panti Pijit & 74 & 95 & 116 \\
\hline $\begin{array}{l}\text { Wahana Permainan berbayar } \\
\text { standar internasional }\end{array}$ & 1 & 1 & 1 \\
\hline Lapangan Golf / drive range & 2 & 2 & 2 \\
\hline Kolam Renang / Water boom & 5 & 4 & 4 \\
\hline Kawasan Heritage & 10 & 7 & 5 \\
\hline
\end{tabular}

Sumber : Dinas Kebudayaan dan Pariwisata Kota Bandung dan diolah kembali oleh penulis. 2016

Dari data jumlah daya tarik wisata pada tabel diatas, terlihat bahwa perkembangan dalam hal pembangunan area-area yang dijadikan daya tarik wisata baru di kota Bandung sangat lambat pertumbuhannya bahkan hampir dapat dikatakan tidak ada pertumbuhan atau perkembangan. Dengan kondisi seperti ini ada permasalahan pokok yang perlu dicari jawaban dan solusinya, apakah kota Bandung untuk masa-masa yang akan datang 3 (tiga) atau 5 (lima) tahun kedepan masih dapat mempertahankan atau meningkatkan jumlah kunjungan wisatawan asal Malaysia hanya dengan mengandalkan konsep wisata belanja saja. Pertanyaan ini perlu dijadikan dasar kiranya pemerintah kota Bandung untuk tetap selalu waspada melalui kegiatan-kegiatan atau strategi preventif atau pencegahan terhadap penurunan jumlah kunjungan wisatawan asal Malaysia melalui pengembangan daya tarik wisatanya secara variatif.

Kemudian dari peningkatan jumlah wisatawan asal Malaysia yang berkunjung ke kota Bandung tersebut dapat dijadikan tolak ukur atas keberhasilan strategi pengembangan pariwisata khususnya dalam hal pengembangan destinasi pariwisata dengan keragaman daya tarik wisata yang dilakukan oleh pemerintah 
kota Bandung melalui Dinas Pariwisata dan Kebudayaan. Oleh karena itu berdasarkan uraian di atas, maka penulis terdorong untuk melakukan penelitian dengan judul: "Strategi Pengembangan Destinasi Pariwisata Kota Bandung Dalam Meningkatkan Tingkat Kunjungan Wisatawan Asal Malaysia"

\section{Strategi dan Destinasi Wisata}

David (2003: 15) menjelaskan bahwa strategi adalah cara untuk mencapai tujuan-tujuan jangka panjang berupa perluasan geografis, diversifikasi,akuisisi, pengembangan produk, penetrasi pasar, rasionalisasi karyawan, divestasi, likuidasi dan joint venture. Disamping itu strategi akan mempengaruhi kehidupan organisasi baik swasta maupun pemerintah dalam jangka panjang dan strategi mempunyai konsekuensi multifungsional atau multidivisional dengan mempertimbangkan factor-faktor internal maupun eksternal yang sedang dihadapi.

Sementara itu, menurut Kusudianto, dalam Prasasia (2013:19), destinasi pariwisata dapat digolongkan berdasarkan ciri-ciri destinasi tersebut, yaitu sebagai berikut:

1. Destinasi sumber daya alam, seperti iklim, pantai dan hutan

2. Destinasi sumber daya budaya, seperti tempat bersejarah, museum, teater dan masyarakat local.

3. Fasilitas rekreasi, seperti taman hiburan.

4. Event, seperti pesta kesenian Bali, pesta Danau Toba dan pasar malam.

5. Aktifitas spesifik, seperti kasino di Genting Highland Malaysia dan wisata Belanja Hongkong.

6. Daya tarik psikologis, seperti petualangan, perjalanan romantic dan keterpencilan.

Dari pengertian destinasi pariwisata berdasarkan kutipan dari Kusudianto tersebut dapat di uraikan bahwa suatu kawasan destinasi memiliki beberapa daya tarik wisata, sebagaimana penjelasan dari Undang-undang kepariwisataan Nomor 10 tahun 2009 yang mendefinisikan bahwa daya tarik wisata adalah segala sesuatu yang memiliki keunikan, keindahan, dan nilai yang berupa keanekaragaman kekayaan alam, budaya, dan hasil buatan manusia yang menjadi sasaran atau tujuan kunjungan wisatawan.

Didalam pengembangan destinasi pariwisata tersebut, Suwantoro (1997:56) menyatakan ada beberapa langkah pokok dalam melakukan strategi pengembangan pariwisata yaitu:

1. Dalam Jangka pendek dititikberatkan pada optimasi

2. Dalam Jangka menengah dititikberatkan pada konsolidasi

3. Dalam Jangka panjang dititikberatkan pada pengembangan dan penyebaran

Sebuah destinasi dapat dikatakan akan melakukan pengembangan wisata jika sebelumnya sudah ada aktivitas wisata. Untuk dapat meningkatkan potensi 
pariwisatanya, yang perlu dilakukan adalah merencanakan pengembangan wisata agar dapat lebih baik dari sebelumnya. Menurut McIntyre ( 1993: 10) ada tiga prinsip utama dalam sustainability development yaitu :

1. Ecological Sustainability, yakni memastikan bahwa pengembangan yang dilakukan sesuai dengan proses ekologi, biologi, dan keragaman sumber daya ekologi yang ada.

2. Social and Cultural Sustainability, yaitu memastikan bahwa pengembangan yang dilakukan memberi dampak positif bagi kehidupan masyarakat sekitar dan sesuai dengan kebudayaan serta nilai-nilai yang berlaku pada masyarakat tersebut.

3. Economic Sustainability, yaitu memastikan bahwa pengembangan yang dilakukan efisien secara ekonomi dan bahwa sumber daya yang digunakan dapat bertahan bagi kebutuhan di masa mendatang.

Sementara itu dilain hal, isu strategis dalam destinasi pariwisata adalah pengelolaan destinasi. Sesuai dengan undang-undang kepariwisataan nomor 10 tahun 2009 dan peraturan pemerintah nomor 38 tahun 2007 tentang pembagian urusan pemerintahan antara pemerintah, pemda provinsi dan pemda kabupaten/kota dapat dijadikan sebagai landasan dalam rangka pengembangan pariwisata dan pengelolaan destinasi pariwisata yang digambarkan sebagai berikut.

\begin{tabular}{|c|c|c|c|}
\hline \multicolumn{2}{|c|}{$\begin{array}{c}\text { Pranata Kemasyarakatan Lokal } \\
\text { Pemberdayaan }\end{array}$} & \multicolumn{2}{|c|}{$\begin{array}{c}\text { Pemerintah } \\
\text { Kebijakan promasyarakat dan } \\
\text { propanata social kemasyarakatan }\end{array}$} \\
\hline & \multirow{2}{*}{\multicolumn{2}{|c|}{$\begin{array}{c}\text { DESTINASI } \\
\text { PARIWISATA }\end{array}$}} & lokal \\
\hline & & & \\
\hline \multicolumn{2}{|c|}{$\begin{array}{c}\text { Pelaku Pariwisata } \\
\text { Investasi terbatas dan terkendali }\end{array}$} & & $\begin{array}{l}\text { Badan Pengelola } \\
\text { Kemitraan }\end{array}$ \\
\hline
\end{tabular}

Gambar 1

Pola Interaksi Unsur Pengelola dengan Destinasi Pariwisata

Sumber: Prasasia. (2013:37)

Menurut Pitana dan Diarta (2009:131) yang mengutip teori Butler, tentang siklus hidup destinasi pariwisata berjalan menurut siklus evolusi yang terdiri dari ;

\begin{tabular}{|c|l|l|}
\hline $\begin{array}{c}\text { No } \\
.\end{array}$ & Tahapan Siklus & \multicolumn{1}{c|}{ Keterangan } \\
\hline 1. & Exploration & $\begin{array}{l}\text { Bentuk kunjungan terbatas dan sporadik dari } \\
\text { orang yang ingin berpetualang }\end{array}$ \\
\hline 2. & Involvement & $\begin{array}{l}\text { Meningkatnya pengunjung yang mendorong } \\
\text { penduduk local menawarkan fasilitas secara } \\
\text { eksklusif kepada pengunjung. }\end{array}$ \\
\hline 3. & Development & Investor luar mulai tertarik untuk menanamkan \\
\hline
\end{tabular}




\begin{tabular}{|l|l|l|}
\hline & & $\begin{array}{l}\text { modalnya guna membangun berbagai fasilitas } \\
\text { pariwisata di suatu destinasi. }\end{array}$ \\
\hline 4. & Consolidation & $\begin{array}{l}\text { Porsi terbesar dari ekonomi local berhubungan } \\
\text { dan bersumber dari pariwisata. }\end{array}$ \\
\hline 5. & Stagnation & $\begin{array}{l}\text { Kapasitas maksimal dari factor penunjang telah } \\
\text { mencapai batas maksimum atau terlampaui. } \\
\text { Jumlah puncak kunjungan tercapai, atraksi buatan } \\
\text { mendominasi atraksi alam dan budaya dan } \\
\text { akhirnya destinasi tidak lagi dianggap menarik. }\end{array}$ \\
\hline 6. & Past-stagnation & $\begin{array}{l}\text { Wisatawan mulai tertarik dengan destinasi lain } \\
\text { yang baru, fasilitas pariwisata digantikan oleh } \\
\text { fasilitas non pariwisata, atraksi wisata menjadi } \\
\text { semakin kurang menarik dan kurang bermanfaat. } \\
\text { Daerah destinasi menjadi terdegradasi } \\
\text { kualitasnya, kumuh dan fasilitasnya tidak } \\
\text { berfungi. }\end{array}$ \\
\hline 2. Recline & Rejuvenation & $\begin{array}{l}\text { Terjadi perubahan dramatis dalam penggunaan } \\
\text { dan pemanfaatan sumber daya pariwisata. Terjadi } \\
\text { penciptaan seperangkat atraksi wisata artificial } \\
\text { baru atau penggunaan sumber daya alam yang } \\
\text { tidak terekploitasi sebelumnya. }\end{array}$ \\
\hline
\end{tabular}

Sumber : Pitana dan Diarta (2009:131)

Di Indonesia pengertian "wisatawan" tercantum dalam UU No. 10 tahun 2009, yaitu Wisatawan adalah orang yang melakukan wisata.

Menurut Suwantoro $(2004 ; 4)$ Wisatawan adalah seseorang atau sekelompok orang yang melakukan perjalanan wisata dengan lama tinggal sekurang-kurangnya 24 jam di daerah asal atau Negara yang di kunjungi.

Sedangkan menurut Oka A. Yoeti wisatawan adalah seseorang yang meninggalkan tempat kediamannya untuk sementara waktu dengan alasan apapun tanpa memangku jabatan untuk pekerjaan di Negara yang di kunjunginya.

Dari definisi di atas dapat disimpulan bahwa Wisatawan adalah seseorang yang melakukan perjalanan wisata untuk sementara waktu atau sekurangkurangnya kebih dari 24 jam.

\section{METODOLOGI PENELITIAN}

Metode yang digunakan dalam penelitian ini adalah metode deskriptifkuantitatif. Menurut Nazir (2003:54), metode deskriptif adalah suatu metode dalam meneliti status sekelompok manusia, suatu objek, suatu set kondisi, suatu sistem pemikiran, ataupun suatu kelas peristiwa pada masa sekarang. Tujuan dari penelitian deskriptif ini adalah untuk membuat deskripsi, gambaran atau lukisan secara sistematis, faktual dan akurat mengenai fakta-fakta, sifat-sifat serta hubungan antara fenomena yang diselidiki. 
Sementara itu menurut Sugiyono (2009), penelitian kuantitatif pada hakikatnya untuk menggali data yang bersifat empirik dan terukur serta data yang diperoleh bisa berbentuk suatu jawaban dari pertanyaan yang dibuat dari kuesioner peneliti terhadap responden di lapangan. Dengan menggunakan pendekatan kuantitatif, data yang didapat akan lebih tuntas, lengkap, lebih mendalam dan bermakna sehingga tujuan penelitian dapat dicapai.

Dalam penelitian ini, metode pengumpulan data yang digunakan adalah data primer dan data sekunder. Data primer diperoleh dengan cara observasi, kuesioner, dan wawancara dengan pihak wisatawan asal Malaysia yang ada di kota Bandung. Data sekunder yang digunakan dalam penelitian ini adalah berasal dari dokumen yang didapatkan dari pihak yang memiliki relevansi dengan kajian penelitian seperti Disbudpar,Air Asia, ASITA,PHRI, dan HPI

Pengukuran terhadap masing-masing indikator dilakukan dengan cara menguraikan indikator penelitian menjadi operasional indikator yang didalamnya menggambarkan variabel yang diteliti. Berikut digambarkan mengenai indikator penelitian yang terdiri dari 2 (dua) jenis yaitu:

a. Indikator penelitian untuk mengukur pengelolaan dan pengembangan destinasi pariwisata menurut Prasasia (2013:102) yang selanjutnya dituangkan dalam daftar pertanyaan sebagai pedoman wawancara kepada para pemangku kepentingan atau unsur terkait antara lain unsur kepemerintahan kota Bandung, unsur pengusaha atau asosiasi industri jasa pariwisata (Hotel, Resturant, Biro Perjalanan, Airline, Hiburan) dan unsur profesi kepemanduan wisata selain responden wisatawan asal Malaysia.

Tabel 3.

Indikator Penilaian Pengelolaan Destinasi Pariwisata

\begin{tabular}{|c|c|c|}
\hline No. & Indikator & Keterangan \\
\hline 1. & $\begin{array}{l}\text { Harmonisasi dan kerjasama dari para pihak yang } \\
\text { terlibat pengelolaan destinasi pariwisata }\end{array}$ & \multirow{10}{*}{$\begin{array}{l}\text { Setiap indikator } \\
\text { dituangkan } \\
\text { dalam bentuk } \\
\text { daftar pertanyaan } \\
\text { dalam } \\
\text { wawancara }\end{array}$} \\
\hline 2. & $\begin{array}{l}\text { Perkembangan aktifitas perekonomian dari } \\
\text { masyarakat sekitar destinasi pariwisata }\end{array}$ & \\
\hline 3. & $\begin{array}{l}\text { Kualitas produk dan pelayanan di destinasi } \\
\text { pariwisata }\end{array}$ & \\
\hline 4. & $\begin{array}{l}\text { Kondisi kesadaran masyarakat dalam melindungi } \\
\text { budaya, alam dan lingkungan }\end{array}$ & \\
\hline 5. & $\begin{array}{l}\text { Pertumbuhan pendapatan asli } \\
\text { pariwisata }\end{array}$ & \\
\hline 6. & Kondisi citra destinasi pariwisata & \\
\hline 7. & Kondisi jejaring destinasi pariwisata & \\
\hline 8. & Pertumbuhan industry berbasis sumber daya local & \\
\hline 9. & Kondisi kepuasan wisatawan & \\
\hline 10 & Terimplementasikannya kearifan local & \\
\hline
\end{tabular}

Sumber: Prasasia (2013:102)

b. Indikator penelitian untuk mengukur tingkat kunjungan wisatawan asal Malaysia ke kota Bandung yang didasarkan pada teori motivasi 
perjalanan menurut MacIntosch yang dikutip oleh Yoeti (2004 : 180) yang terdiri dari 4 (empat) hal yaitu, Physical Motivation, Cultural Motivation, International Motivation and Prestige Motivation. dan selanjutnya dituangkan dalam daftar pertanyaan sebagai pedoman pertanyaan dalam kuesioner.

Tabel 4.

Indikator Penilaian Wisatawan Asal Malaysia Terhadap Daya Tarik Wisata Berdasar Motivasi Kunjungannya

\begin{tabular}{|c|c|c|}
\hline No. & Indikator & Keterangan \\
\hline 1. & Motivasi dan Tujuan Relaksasi & \multirow{8}{*}{$\begin{array}{l}\text { Setiap indikator } \\
\text { dituangkan dalam bentuk } \\
\text { kuesioner }\end{array}$} \\
\hline 2. & Motivasi dan tujuan Pengobatan & \\
\hline 3. & Motivasi kesenangan (Leisure) & \\
\hline 4. & Eksplorasi Kebudayaan dan Sejarah & \\
\hline 5. & Motivasi Olah Raga & \\
\hline 6. & Motivasi Kunjungan Keluarga & \\
\hline 7. & Motivasi spiritual dan keagamaan & \\
\hline 8. & Motivasi Adat Istiadat & \\
\hline
\end{tabular}

Sumber : Yoeti (2004 : 180)

HASIL DAN PEMBAHASAN

Tabel 5

Hasil Wawancara Penilaian Pengelolaan Destinasi dengan 4 (Empat) Asosiasi, 1 (Satu) Perusahaan Airline dan 1 (Satu) Instansi Pemkot Bandung (Dinas Pariwisata)

\begin{tabular}{|c|c|c|c|c|c|}
\hline No & Indikator & Kurang & Cukup & Baik & $\begin{array}{c}\text { Sangat } \\
\text { Baik }\end{array}$ \\
\hline 1 & $\begin{array}{l}\text { Harmonisasi dan kerjasama dari para } \\
\text { pihak yang terlibat pengelolaan } \\
\text { destinasi pariwisata }\end{array}$ & 4 & 1 & 1 & \\
\hline 2 & $\begin{array}{l}\text { Perkembangan aktifitas } \\
\text { perekonomian dari masyarakat } \\
\text { sekitar destinasi pariwisata }\end{array}$ & & 5 & 1 & \\
\hline 3 & $\begin{array}{l}\text { Kualitas produk dan pelayanan di } \\
\text { destinasi pariwisata }\end{array}$ & & 4 & 2 & \\
\hline 4 & $\begin{array}{l}\text { Kondisi kesadaran masyarakat } \\
\text { dalam melindungi budaya, alam dan } \\
\text { lingkungan }\end{array}$ & 6 & & & \\
\hline 5 & $\begin{array}{l}\text { Pertumbuhan pendapatan asli daerah } \\
\text { dari pariwisata }\end{array}$ & & & 4 & 2 \\
\hline 6 & Kondisi citra destinasi pariwisata & 3 & 2 & 1 & \\
\hline
\end{tabular}




\begin{tabular}{|c|l|c|c|c|c|}
7 & Kondisi jejaring destinasi pariwisata & & & 6 & \\
\hline 8 & $\begin{array}{l}\text { Pertumbuhan industri berbasis } \\
\text { sumber daya local }\end{array}$ & & 1 & 5 & \\
\hline 9 & Kondisi kepuasan wisatawan & 1 & 4 & 1 & \\
\hline 10 & $\begin{array}{l}\text { Terimplementasikannya kearifan } \\
\text { loal }\end{array}$ & & 5 & 1 & \\
\hline
\end{tabular}

Sumber: Data yang diolah pada tahun 2016

\section{Analisa Kuisioner Motivasi Wisatawan Malaysia ke Bandung}

Penyebaran kuesioner sebanyak 100 lembar sesuai dengan sampel yang telah ditentukan dilakukan oleh penulis dalam periode bulan April-Juni 2016 dengan jadwal 2 x dalam 1 minggu pada hari biasa dan hari libur. Adapun area penyebaran kuesioner sebagai berikut:

\section{Tabel 6}

Distribusi Kuesioner

\begin{tabular}{|c|l|c|}
\hline No. & \multicolumn{1}{|c|}{ Area } & Jumlah Responden \\
\hline 1. & Bandara & 15 \\
\hline 2. & Stasiun & 5 \\
\hline 3. & Terminal Leuwi Panjang & 5 \\
\hline 4. & Trans Studio Mall & 10 \\
\hline 5. & Pasar Baru & 20 \\
\hline 6. & BTC Pasteur & 10 \\
\hline 7. & Bandung Indah Plaza & 5 \\
\hline 8. & Jl. Riau & 15 \\
\hline 9. & Paris Van Java & 5 \\
\hline 10. & Ciwalk/Cihampelas & 10 \\
\hline \multicolumn{2}{|c|}{ Total } & $\mathbf{1 0 0}$ \\
\hline
\end{tabular}

Sumber: Hasil olahan tim peneliti, 2016

Dari hasil kuisioner yang disebarkan oleh penulis responden dikelompokan berdasarkan Jenis Kelamin, hasilnya adalah sebagai berikut:

Tabel 7

Jenis Kelamin Responden

\begin{tabular}{|l|l|l|l|}
\hline No & Jenis Kelamin & Jumlah & Persen \\
\hline 1 & Pria & 41 Orang & $41 \%$ \\
\hline 2 & Wanita & 59 Orang & $59 \%$ \\
\hline \multicolumn{2}{|l|}{ Total } & 100 Orang & $100 \%$ \\
\hline
\end{tabular}

Sumber: Data yang diolah pada tahun 2016

Dari data tabel 7 dapat disimpulkan bahwa mayoritas wisatawan Malaysia yang datang ke Kota Bandung ialah wanita dilihat dari jumlah 100 
jumlah responden 59 orang responden atau $59 \%$ wanita dan 41 responden atau $41 \%$ Pria. berikut:

Responden dikelompokan berdasarkan Jenis Kelamin, hasilnya sebagai

Tabel 8

Rentan Usia Responden

\begin{tabular}{|l|l|l|l|}
\hline No & Rentan Usia & Jumlah & Persen \\
\hline 1 & $<17$ & 24 Orang & $24 \%$ \\
\hline 2 & $18-35$ & 48 Orang & $48 \%$ \\
\hline 3 & $>35$ & 28 Orang & $28 \%$ \\
\hline \multicolumn{2}{|l|}{ Total } & 100 Orang & $100 \%$ \\
\hline
\end{tabular}

Sumber: Data yang diolah pada tahun 2016

Dari data tebel 8 dapat disimpulkan bahwa mayoritas wisatawan Malaysia yang datang ke Kota Bandung memiliki rentan usia 18-35 dilihat dari 100 jumlah responden 48 orang responden atau $48 \%$ berusia 18-35 tahun, 28 orang responden atau $28 \%$ berusia lebih dari 35 tahun dan 24 orang responden atau 24 $\%$ kurang dari 17 tahun. Responden dikelompokan berdasarkan Kepercayaan atau Agama, hasilnya ialah sebagai berikut:

Tabel 9

Kepercayaan atau Agama Responden

\begin{tabular}{|l|l|l|l|}
\hline No & Agama & Jumalh & Persen \\
\hline 1 & Islam & 77 Orang & $77 \%$ \\
\hline 2 & Katolik & 10 Orang & $10 \%$ \\
\hline 3 & Protestan & 5 Orang & $5 \%$ \\
\hline 4 & Hindu & 5 Orang & $5 \%$ \\
\hline 5 & Budha & 3 Orang & $3 \%$ \\
\hline \multicolumn{2}{|l|}{ Total } & 100 Orang & $100 \%$ \\
\hline
\end{tabular}

Sumber: Data olahan, 2016

Dari data tebel 9 dapat disimpulkan bahwa mayoritas wisatawan Malaysia yang datang ke Kota Bandung memiliki keyakinan beragama Islam dilihat dari jumlah responden 100 jumlah responden 77 orang atau $77 \%$ beragama Islam, 10 orang responden atau $10 \%$ beragama katolik, 5 orang responden atau $5 \%$ beragama protestan, 5 orang responden atau $5 \%$ beragama Hindu dan 3 orang responden atau $3 \%$ beragama Hindu. Responden dikelompokan berdasarkan tingkat pendididkan, hasilnya ialah sebagai berikut: 
Table 10.

Tingkat Pendidikan Responden

\begin{tabular}{|l|l|l|l|}
\hline No & $\begin{array}{l}\text { Tingkat } \\
\text { Pendidikan }\end{array}$ & Jumlah & Persen \\
\hline 1 & SD & 3 Orang & $3 \%$ \\
\hline 2 & SMP & 20 Orang & $20 \%$ \\
\hline 3 & SMA & 25 Orang & $25 \%$ \\
\hline 4 & S1 & 40 Orang & $40 \%$ \\
\hline 5 & Lainnya & 12 Orang & $12 \%$ \\
\hline \multicolumn{2}{|l|}{ Total } & 100 Orang & $100 \%$ \\
\hline
\end{tabular}

Sumber: Data olahan, 2016

Dari data tebel 10 dapat disimpulkan bahwa mayoritas wisatawan Malaysia yang datang ke Kota Bandung memiliki pendidikan S1 dilihat dari 100 orang jumlah responden 40 orang responden atau $40 \%$ berpendidikan S1, 3 orang responden atau $3 \%$ berpendidikan SD, 20 orang responden atau $20 \%$ berpendidikan SMP, 25orang responden atau $25 \%$ berpendidikan SMA dan 12 orang responden atau $20 \%$ berpendidikan lain-lain. Responden dikelompokan berdasarkan jenis pekerjaan, hasilnya ialah sebagai berikut:

Tabel 11.

Jenis Pekerjaan Responden

\begin{tabular}{|l|l|l|l|}
\hline No & Jenis Pekerjaan & Jumlah & Persen \\
\hline 1 & Pelajar & 5 Orang & $5 \%$ \\
\hline 2 & PNS & 15 Orang & $15 \%$ \\
\hline 3 & Wirausaha & 35 Orang & $35 \%$ \\
\hline 4 & IRT & 25 Orang & $25 \%$ \\
\hline 5 & Lain-lain & 20 Orang & $20 \%$ \\
\hline \multicolumn{2}{|l|}{ Total } & 100 Orang & $100 \%$ \\
\hline
\end{tabular}

Sumber: Data olahan, 2016

Dari data tebel 11 dapat disimpulkan bahwa mayoritas wisatawan Malaysia yang datang ke Kota Bandung memiliki pekerjaan wirausaha dilihat dari 100 orang jumlah responden 35 orang responden atau $35 \%$ memiliki pekerjaan sebagai wirausaha, 5 orang responden atau $5 \%$ memiliki pekerjaan sebagai pelajar, 15 orang responden atau $15 \%$ memiliki pekerjaan sebagai PNS, 25 orang responden atau $25 \%$ memiliki pekerjaan sebagai ibu rumah tangga (IRT) dan 20 orang responden atau $20 \%$ memiliki pekerjaan lain-lain. Responden dikelompokan berdasarkan pendapatan, hasilnya ialah sebagai berikut: 
Tabel 12. Pendapatan Responden

\begin{tabular}{|r|c|c|c|}
\hline No & $\begin{array}{c}\text { Penghasilan } \\
\text { Perbulan }\end{array}$ & Jumlah & Persen \\
\hline 1 & $<$ RM. 1.500 & 8 Orang & $8 \%$ \\
\hline 2 & $\begin{array}{c}\text { RM.1.501- } \\
2.000\end{array}$ & 15 Orang & $15 \%$ \\
\hline 3 & $\begin{array}{c}\text { RM. } 2.001- \\
2.500\end{array}$ & 25 Orang & $25 \%$ \\
\hline 4 & $\begin{array}{c}\text { RM. } 2.501- \\
3.000\end{array}$ & 40 Orang & $40 \%$ \\
\hline 5 & $>$ RM. 3.001 & 12 Orang & $12 \%$ \\
\hline & Total & $\begin{array}{l}100 \\
\text { Orang }\end{array}$ & $100 \%$ \\
\hline
\end{tabular}

Sumber: Data olahan, 2016

Dari data tebel 12 dapat disimpulkan bahwa mayoritas wisatawan Malaysia yang datang ke Kota Bandung memiliki pendapatan RM. 2.502-3.000 dilihat dari 100 orang jumlah responden 40 orang responden atau $40 \%$ berpenghasilan RM. 2.502-3.000, 8 orang responden atau $8 \%$ berpenghasilan RM $1.500,15$ orang responden atau $15 \%$ berpenghasilan RM 1.501-2.000, 25 orang responden atau 25\% berpenghasilan RM 2.001-2.500, 12 orang responden atau 12 $\%$ memiliki penghasilan >RM. 3.001. Responden dikelompokan berdasarkan frekuensi kunjungan, hasilnya ialah sebagai berikut :

Tabel 13.

Frekuensi Kunjungan Responden

\begin{tabular}{|c|l|c|c|}
\hline No & Frekuensi Kunjungan & Jumlah & Persen \\
\hline 1 & 1x dalam sebulan & 35 Orang & $35 \%$ \\
\hline 2 & $>1$ x Sebulan & 3 orang & $3 \%$ \\
\hline 3 & 1 x dalam setahun & 50 Orang & $50 \%$ \\
\hline 4 & $>1$ x dalam setahun & 12 Orang & $12 \%$ \\
\hline \multicolumn{2}{|c|}{ Total } & 100 & Orang \\
\cline { 2 - 4 } & $100 \%$ \\
\hline
\end{tabular}

Sumber: Data olahan, 2016

Dari data tebel 13 dapat disimpulkan bahwa mayoritas wisatawan Malaysia yang datang ke Kota Bandung memiliki frekuensi kunjungan $1 \mathrm{x}$ dalam setahun dapat dilihat dari 100 orang jumlah responden 50 orang responden atau 50 $\%$ memiliki frekuensi kunjungan $1 \mathrm{x}$ dalam setahun, 35 orang responden atau 35 $\%$ memiliki frekuesi kunjungan 1x dalam sebulan, 3 orang responden atau $3 \%$ memiliki frekuensi kunjungan $>1 \mathrm{x}$ dalam sebulan dan 12 orang reasponden atau 
$12 \%$ memiliki frekuensi kunjungan> $1 \mathrm{x}$ dalam setahun. Responden dikelompokan berdasarkan motivasi kunjungan, hasilnya ialah sebagai berikut:

Tabel 14.

Motivasi Responden Wisatawan Asal Malaysia

\begin{tabular}{|c|c|c|c|}
\hline No & Motivasi & Jumlah & Persen \\
\hline 1 & Relaksasi dan Kesehatan & 5 Orang & $5 \%$ \\
\hline 2 & Budaya dan Adat & 8 Orang & $8 \%$ \\
\hline 3 & Kerja atau Bisnis & 12 Orang & $12 \%$ \\
\hline 4 & Kesenangan dan Belanja & 70 Orang & $70 \%$ \\
\hline 5 & Motivasi alam dan lainnya & 5 Orang & $5 \%$ \\
\hline \multicolumn{2}{|c|}{ Total } & 100 Orang & $100 \%$ \\
\hline
\end{tabular}

Sumber: Data olahan, 2016

Dari data tebel 14 dapat disimpulkan bahwa mayoritas wisatawan Malaysia yang datang ke Kota Bandung dengan Motivasi untuk kesenangan dan belanja dapat dilihat dari 100 jumlah responden 70 orang responden atau $70 \%$ memiliki mtoivasi untuk kesenangan dan belanja, 12 orang responden atau $12 \%$ memiliki motivasi untuk Kerja atau bisnis, 8 orang responden atau $8 \%$ memiliki motivasi Budaya dan adat, dan motivasi relaksasi dan kesehatan serta motivasi alam atau lainnya masing-masing 5 orang atau $5 \%$.

\section{SIMPULAN DAN SARAN}

\section{SIMPULAN}

Setelah dilakukan serangkaian pengumpulan data, pengolahan data, penyebaran kuesioner dan tabulasi data dengan tujuan untuk mengetahui permasalahan strategi pengembangan destinasi pariwisata Bandung yang sedang dan akan dilakukan guna meningkatkan atau menjaga kestabilan jumlah kunjungan wisatawan asal Malaysia atau kemungkinan adanya ancaman terhadap penurunan jumlah kedatangan wisatawan asal Malaysia yang dikarenakan berbagai faktor internal dan eksternal. Dari kegiatan penulis tersebut dapat disimpulkan sebagai berikut:

1) Aspek pengelolaan destinasi pariwisata di kota Bandung, dari empat responden yang terdiri asosiasi usaha pariwisata, satu airline dan satu instansi pemerintah didapatkan kesimpulan dari masing-masing indikator yaitu,

a. Kondisi kesadaran masyarakat dalam melindungi budaya, alam dan lingkungan, $100 \%$ responden memberikan penilaian kurang.

b. Kondisi Harmonisasi dan kerjasama dari para pihak yang terlibat pengelolaan destinasi pariwisata, $66,7 \%$ responden memberikan penilaian kurang. 
c. Kondisi citra destinasi pariwisata Bandung, $60 \%$ responden memberikan penilaian kurang.

d. Sedangkan untuk kondisi indikator lainnya, rata-rata $55 \%$ dari total responden memberikan nilai cukup.

2) Sedangkan dari aspek responden wisatawan dapat disimpulkan bahwa.

a. Jenis kelamin perempuan adalah mayoritas wisatawan asal Malaysia yang datang ke Bandung dengan jumlah prosentase $59 \%$ responden.

b. Usia 18-35 tahun dari wisatawan asal Malaysia yang datang ke Bandung merupakan jumlah mayoritas dengan prosentase $48 \%$ responden.

c. Agama Islam juga merupakan jumlah prosentase tertinggi sebesar $70 \%$.

d. Untuk tingkat pendidikan di dominasi oleh wisatawan yang berpendidikan S1 dengan jumlah $40 \%$.

e. Jenis pekerjaan wisatawan asal Malaysia yaitu wirausaha mendapatkan penilaian $35 \%$.

f. Tingkat pendapatan responden sebesar RM.2.501-RM.3000 sebanyak 40\% responden.

g. Frekwensi kunjungan responden ke Bandung 1 x dalam 1 tahun merupakan sebanyak $50 \%$ responden.

h. Motivasi kunjungan responden ke Bandung untuk wisata belanja hingga saat ini sebanyak $70 \%$

3) Kesimpulan secara umum dari dua jenis indikator penilaian tersebut memberikan penjelasan bahwa

a. Kegiatan pengembangan destinasi pariwisata kota Bandung hingga saat ini menurut data yang ada masih kurang bahkan cenderung citranya mulai turun dan kondisi masyarakatnya kurang kesadarannya dalam ikut serta menjaga kondisi dan lingkungan yang ada sehingga dapat dikatakan statis terbukti dengan adanya data tentang jumlah dan jenis daya tarik wisata yang ada sejak 3 s.d. 5 tahun yang lalu masih belum ada penambahan bahkan malah ada pengurangan.

b. Wisatawan asal Malaysia yang masih mendominasi adalah jenis kelamin wanita dengan umur 18-35 tahun dengan tujuan belanja, hal ini dimungkinkan kebenarannya karena sesuai data yang ada masih belum adanya daya tarik wisata baru yang dapat ditawarkan.

\section{SARAN}

1. Pemerintah kota Bandung segera melakukan kegiatan-kegiatan preventive dalam pengembangan destinasi pariwisatanya untuk menanggulangi kemungkinan akan terjadinya penurunan jumlah kunjungan wisatawan asal Malaysia yang suatu saat akan mengalami kejenuhan karena tidak adanya daya tarik wisata pilihan lainnya, yang juga karena ketertarikannya dengan daerah lain yang juga sedang gencar melakukan promosi-promosi serta menawarkan daya tarik wisata yang baru. 
2. Sosialisasi, pendekatan persuasif dan kampanye kepada masyarakat umum dan pelaku usaha terus ditingkatkan untuk menjaga dan mengembangkan kekayaan dan potensi pariwisata yang ada di kota Bandung.

3. Point 1 dan 2 tersebut benar-benar harus diperhatikan karena tidak menutup kemungkinan kondisi stagnation yang merupakan bagian dari tahapan siklus hidup destinasi pariwisata dapat dialami oleh Bandung, sebagaimana yang dikutip oleh Pitana dan Diarta (2009:131) dari teori Butler, tentang siklus hidup destinasi pariwisata berjalan menurut siklus evolusi

\section{DAFTAR PUSTAKA}

Bandung Kota tujuan Wisata Dunia (2013). Diakses tanggal 7 Mei 2016, http://www1.jabarprov.go.id/index.php/news/7445/2013/10/16,

David, F, R. (2004). Manajemen Strategi : konsep-konsep. Jakarta :PT. Index.

InilahKoran (2016). Diakses tanggal 3 Maret 2016

Jadwal Penerbangan Air Asia dari Bandung (2016). Diakses tanggal 7 Mei 2016, http://www.airasia.com

McInteyre, G. (1993). Sustainable Tourism Development, Guide for Local Planners. World Tourism Organization.

Nazir, M. (2003). Metode Penelitian. Jakarta: Ghalia Indonesia.

Perda Kota Bandung No. 13 (2007), Tentang tugas pokok dan fungsi dinas kebudayaan dan pariwisata kota Bandung.

Peraturan Pemerintah Nomor 38 (2007). Tentang pembagian urusan pemerintahan antara pemerintah, pemda provinsi dan pemda kabupaten/kota

Penduduk Kota Bandung (2015). Diakses tanggal 23 Mei 2016. http://disdukcapil.bandung.go.id

Prasiasa, D, P, O. (2013). Destinasi Pariwisata Berbasis Masyarakat. Jakarta: Salemba Humanika.

Pitana, I.G., \& Diarta.I, K, S. (2009). Pengantar Ilmu Pariwisata.Yogyakarta: Andi.

Rangkuti, F. (2008). Analisis Swot Teknik Membedah Kasus Bisnis. Jakarta:PT. Gramedia Pustaka Umum.

Suwantoro, G (2004). Dasar-dasar Pariwisata, Upaya Pengembangan Pariwisata Alternatif. Andi; Yogyakarta 
Sugiyono, (2009). Metode Penelitian Kuantitatif, Kualtatif dan R\&D. CV. Yogyakarta: Alfabeta.

Tribunnews.com (2016). Diakses tanggal 9 Pebruari 2016.

Undang-undang No. 10 (2009), tentang kepariwisataan. Dikases 20 Maret 2016

World Trade Organization. Diakses tanggal 7 Mei 2016. Dari http://www.Unwto.org

Yoeti. O. A. (2006). Pariwisata Budaya, Masalah dan solusinya. Jakarta: PT. Pradnya Parami 